\title{
MAKALAH RENANG
}

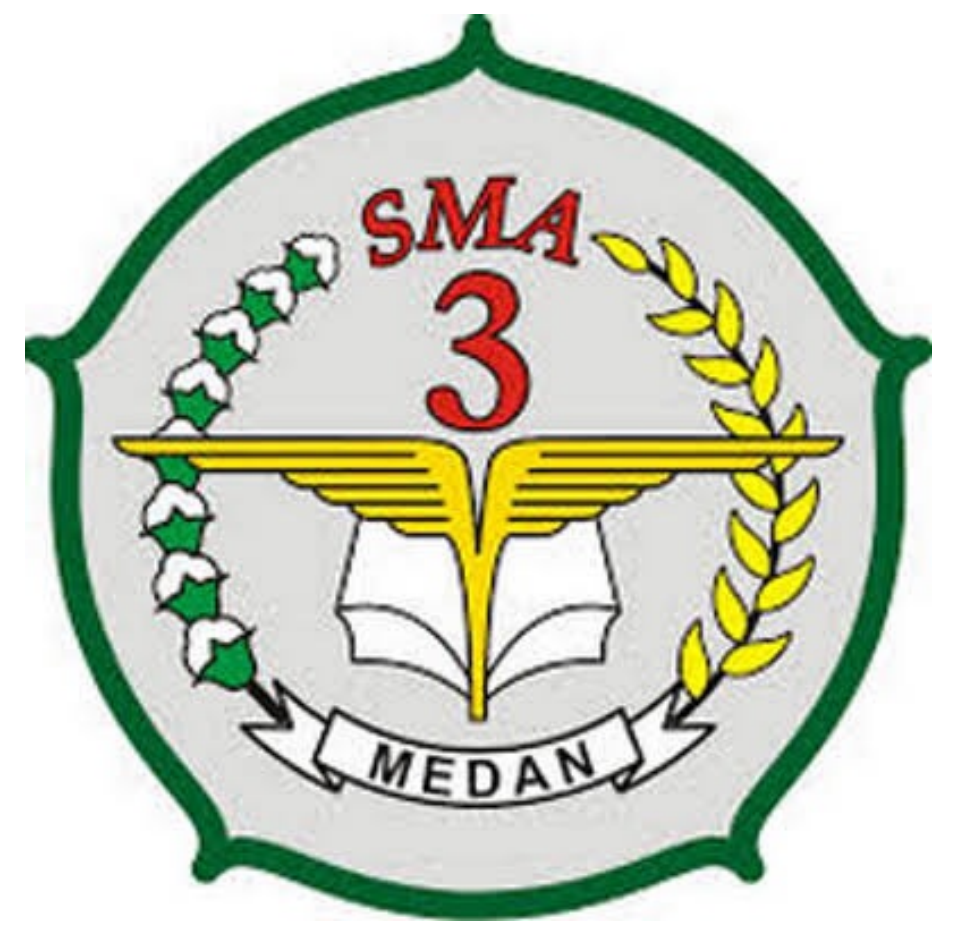

DISUSUN OLEH :

FAISSA WIHANDI

X MIA 1

Pendidikan Jasmani, Olahraga, dan Kesehatan SMA NEGERI 3 MEDAN

TAHUN AJARAN 2019/2020 


\section{Kata Pengantar}

Segala puji bagi Allah SWT atas segala rahmat yang telah di berikan kepada saya, sehingga saya dapat menyusun makalah ini, mengenai aktivitas air, yaitu renang.

Makalah ini saya buat agar dapat dimengerti oleh saya sendiri dan orang lain. Apabila terdapat kesalahan, mohobn berikan kritik dan saran yang bersifat membangun. Agar saya bisa melakukan perbaikan dalam pembuatan makalah selanjutnya.

Akhir kata, mudah-mudahan makalah ini dapat memberi manfaat dalam kegiatan belajar mengajar, khususnya di sekolahan. Sehingga dapat mempermudah dalam proses belajar mengajar. 


\section{BAB I}

\section{PENDAHULUAN}

\subsection{Latar Belakang}

Di Indonesia mengenai berenang baru mulai terkenal setelah kemerdekaan, sedangkan sebelumnya hanya dikenal oleh bangsa kulit putih saja. Berenang merupakan cabang olahraga yang penting untuk dipelajari dan dikuasai, sebab manusia hidup didunia ini, sehari-harinya tidak lepas dari pada air. Air adalah salah satu unsur yang penting didalam kehidupan kita, sebab bila tidak ada air tentu semua mahluk tidak dapat hidup. Selain itu berenang merupakan olahraga yang paling dianjurkan bagi mereka yang kelebihan berat badan (obesitas), ibu hamil dan penderita gangguan persendian tulang atau arthritis. Berenang dapat memberikan banyak manfaat yang dapat dirasakan apabila kita melakukannya secara benar dan rutin.

Namun kenyataannya, banyak yang enggan mempelajari cabang olahraga tersebut, karna di anggap berbahaya. Padahal berenang terbilang minim resiko, olahraga renang membuat tubuh sehat karena hampir semua otot tubuh dipakai sewaktu berenang.

Untuk menghindari terjadinya bahaya yang di khawatirkan, dianjurkan melakukan gerakan pemanasan sebelum memulai olahraga ini, agar tidak kram otot sekaligus juga berfungsi untuk meningkatkan suhu tubuh dan detak jantung secara bertahap dan juga lakukan pendinginan setelah selesai berenang agar suhu tubuh dan detak jantung tidak menurun secara drastis dengan cara berenang perlahan-lahan selama 5 menit.

\subsection{Rumusan Masalah}

1.2.1 Bagaimanakah sejarah dari cabang olahraga renang?

1.2.2 Bagaimana tehnik berolahraga renang? 
1.2.3 Apa saja jenis-jenis gaya dalam renang?

1.2.4 Bagaimana proses belajar mengajar dalam cabang olahraga renang?

1.2.5 Peraturan apa saja yang ada dalam cabang olahraga renang?

1.2.6 Sarana dan prasarana apa saja yang diperlukan dalam olahraga renang?

1.2.7 Apa saja manfaat olahraga renang?

\subsection{Tujuan Penulisan}

1.3.1 Untuk mengetahui sejarah dari cabang olahraga renang.

1.3.2 Untuk mengetahui tehnik berolahraga renang.

1.3.3 untuk mengetahui jenis-jenis gaya dalam olahraga renang.

1.3.4 Untuk mengetahui proses belajar mengajar dalam cabang olahraga renang.

1.3.5 Untuk mengetahui peraturan-peraturan dalam cabang olahraga renang.

1.3.6 Untuk mengetahui sarana dan prasarana yang diperlukan dalam renang.

1.3.7 untuk mengetahui manfaat dari melakukan ola

hraga renang.

\subsection{Manfaat Penulisan}

1.4.1 Pembaca dapat mengetahui sejarah dari cabang olahraga renang.

1.4.2 Pembaca dapat mengetahui tehnik berolahraga renang.

1.4.3 Pembaca dapat mengetahui jenis-jenis gaya apa saja dalam renang.

1.4.4 Pembaca dapat mengetahui proses pembelajaran dalam cabang olahraga renang. 
1.4.5 Pembaca dapat mengetahui peraturan-peraturan dalam olahraga renang.

1.4.6 Pembaca dapat mengetahui sarana dan prasarana yang diperlukan untuk renang.

1.4.7 Pembaca dapat mengetahui manfaat dari pentingnya melakukan olahraga renang. 


\section{Bab 2}

\section{Pembahasan}

\subsection{Sejarah renang}

\section{A. Sejarah Renang di Dunia}

Renang sudah ada sejak zaman prasejarah, pada saat itu renang digunakan untuk bertahan hidup karena belum ada alat transportasi yang memadai.

Bukti perkembangan sejarah olahraga pada masa prasejarah terlihat dari relief yang terdapat di dinding gua. Dengan adanya ditemukan lukisan yang perkiraan usia 4000 SM di padang pasir Kebir menjadi salah satu penemuan terkenal. Dokumen lainnya seperti dalam Epos Gilgamesh, Oddysey, Iliad,dan Alkitab juga mencatat adanya kegiatan berenang pada masa itu.

Sekitar tahun 1800 , tepatnya pada tahun 1828 , perlombaan renang diadakan di Eropa dengan dibangunnya kolam renang yang dibuka secara umum. Pada saat itu, gaya yang berkembang hanya berupa gaya dada dan itulah gaya yang menjadi awal lahirnya sejarah renang gaya dada yang kemudian diikuti munculnya dengan gaya-gaya baru dalam olahraga renang.

\section{B. Sejaran Renang di Indonesia}

Di Indonesia sejarah renang dimulai dari zaman Kerajaan Majapahit. Pada masa Kerajaan Majapahit renang bertujuan masih ditujukan untuk menangkap ikan, berperang dan melakukan pembajakan pada kapal-kapal musuh.

Beberapa bukti adanya aktivitas renang di Indonesia ditandai dengan ditemukannya relief atau gambar yang terdapat di dinding candi. 
Pada bangunan peninggalan kerajaan masa lampau juga dapat kita temui

kolam-kolam air yang digunakan untuk berenang, seperti situs Taman Sari (Water Castle) yang terdapat di Yogyakarta.

Peninggalan itulah yang menjadi bukti kuat bahwa renang memang sudah ada dari zaman kerajaan masa lampau. Namun, belum dapat dipastikan gaya renang apa yang digunakan pada masa itu.

Di Indonesia, pembangunan kolam renang untuk pertama kalinya dibangun di Cihampelas, Bandung pada tahun 1904, kemudian diikuti pembangunan kolam renang Brantas di Surabaya dan kolam renang Cikini di Jakarta yang diperuntukkan hanya untuk orang-orang kulit putih (bukan pribumi).

Perlombaan cabang olahraga renang di Indonesia untuk pertama kalinya diselenggarakan pada tahun 1948 di kota Surakarta di Pekan Olahraga Nasional (PON). Gaya renang yang diperlombakan pada saat itu adalah gaya bebas, gaya punggung, dan gaya dada.

\section{$2.2 \quad$ Teknik Renang}

Ada banyak gaya berenang yang dikenal saat ini. Akan tetapi, sebelum mempelajari berbagai macam gaya berengang, ada beberapa teknik dasar yang perlu diketahui. Sebagai berikut.

\section{Teknik Pernapasan}

Kemampuan mengatur napas adalah kunci keberhasilan seorang perenang. Untuk melatihnya, berdirilah di tepi kolam dengan rendah dan wajah berada di atas permukaan air. Tarik napas melalui mulut, tahanlah selama beberapa saat. Masukkan kepala ke dalam air, lalu embuskan napas melaui hidung. 
Latihan pernapasan ini sebaiknya Anda lakukan sebanyak 10 hingga 15 kali setiap selesai melakukan gerakan atau latihan. Ulangi latihan tersebut secara rutin sampai Anda menemukan irama sendiri.

\section{Teknik Mengapung}

Kunci untuk belajar mengapung atau mengambang adalah tubuh harus rileks dan tidak panik. Ada dua posisi mengapung yang perlu Anda kuasai, yaitu mengambang dalam posisi telentang dan mengambang berdiri.

Untuk mengapung telentang, berdirilah dengan kaki menginjak dasar kolam dan kepala menghadap ke atas. Pegang tepi kolam, tarik badan ke belakang secara perlahan dengan posisi tangan lurus sampai telinga terendam air. Lakukan 10-15 kali sampai Anda menemukan posisi seimbang yang pas.

Teknik mengapung berdiri dilakukan dengan menyelam ke dalam air sambil tangan tetap berpegangan pada tepi kolam. Tarik napas dalam-dalam dan tahan, lalu dorong badan Anda menjauhi kolam sambil menggerakkan kaki seperti saat berenang gaya dada dan tangan seperti ayam mengepakkan sayap.

\section{Teknik Meluncur}

Meluncur adalah menggerakkan tubuh secara horizontal di bawah permukaan air. Untuk melakukannya, turunlah ke kolam yang dangkal dan berdirilah dengan membelakangi dinding kolam. Tempelkan salah satu telapak kaki ke dinding tepi kolam dengan jari-jari ke arah bawah sebagai tolakan untuk meluncur.

Doronglah badan menggunakan kaki tersebut dan meluncurlah sejauh mungkin dengan kedua tangan lurus sejajar ke arah depan. Usahakan agar posisi kepala masuk ke dalam air sehingga telinga sejajar dengan lengan. Lakukan latihan ini sebanyak 10 hingga 15 kali sampai Anda menemukan keseimbangan. 


\subsection{Jenis-jenis Gaya Renang}

Berenang dapat dilakukan dengan beberapa macam gaya, di antaranya gaya katak, gaya dada, gaya bebas, dan gaya kupu-kupu. Seperti apa dan bagaimana cara berenang dengan gaya-gaya tersebut? Berikut ini penjelasan mengenai gaya berenang menurut Federasi Renang Internasional.

\section{Gaya Katak (Gaya Dada)}

Gaya berenang yang satu ini dinamakan gaya katak karena gerakannya persis seperti gerakan katak saat berenang. Gaya katak atau gaya dada adalah gaya berenang yang sangat populer untuk renang rekreasi, tetapi juga sering digunakan oleh para atlet dalam berlomba.

Dalam gaya dada, tubuh diposisikan secara stabil seperti merangkak di permukaan air, dikombinasikan dengan gerakan kaki dan tangan. Tangan dan kaki berada di dalam air, sedangkan kepala digerakkan naik turun dari dalam ke permukaan air sehingga Anda dapat melihat ke depan ketika berenang.

Meskipun sama-sama menghadap ke arah permukaan air, gaya katak berbeda dengan gaya bebas. Pada gaya katak, tubuh selalu dalam keadaan tetap. Bernapas dapat Anda lakukan saat mulut sedang berada di atas permukaan air dalam waktu lama.

Kaki dan tangan digerakkan secara bergantian. Pada saat kaki bergerak menendang ke arah luar, kedua belah tangan diposisikan lurus ke depan. Sebaliknya, pada saat kaki dalam posisi lurus, kedua tangan digerakkan seperti sedang membelah air sehingga badan tertarik ke arah depan. 


\section{Gaya Bebas}

Sesuai namanya, gaya bebas tidak terikat pada teknik atau aturan dasar tertentu. Dibandingkan gaya berenang lainnya, gaya bebas akan membuat tubuh Anda melaju lebih cepat karena dapat dilakukan dengan beraneka ragam gerakan dalam berenang.

Gaya bebas ini sering dilakukan baik oleh para pemula maupun perenang profesional. Renang gaya bebas dilakukan dengan menelungkup, yaitu posisi badan dan wajah menghadap permukaan air, lalu kaki dan tangan bergerak untuk menarik dan menendang air.

Tangan digerakkan bergantian dengan gerakan seperti mengayuh, sedangkan kaki digerakkan ke atas dan ke bawah. Untuk mengambil napas, Anda dapat menoleh ke arah kanan atau kiri di atas permukaan air. Lakukan saat lengan digerakkan keluar dari air sehingga posisi tubuh menjadi miring.

\section{Gaya Punggung}

Gaya ini dinamakan gaya punggung karena posisi punggung menghadap ke permukaan air atau tubuh telentang. Posisi ini memudahkan Anda untuk bernapas dan membuka mata, tetapi sulit menentukan arah gerakan tubuh.

Gaya punggung merupakan gaya renang tertua setelah gaya bebas dan diperlombakan pertama kali di Olimpiade Paris pada tahun 1900. Gaya punggung tidak diawali dari atas balok start, tetapi dari dalam kolam dengan tangan berpegangan, lutut ditekuk, dan telapak kaki bertumpu ke dinding kolam.

Pada gaya punggung, kaki bergerak lebih aktif ke arah atas dan pergelangan kaki harus dijaga agar selalu lentur, tidak kaku. Gerakan tangan pada gaya punggung hampir sama dengan gaya bebas, yaitu digerakkan menuju pinggang seperti sedang mengayuh. 


\subsection{Proses Pembelajaran Renang}

Berikut ini ialah tahapan proses yang perlu dilakukan dalam kegiatan pembelajaran renang.

1. Pengenalan Air

Sebagian besar anak-anak, bahkan orang dewasa yang belum pernah masuk ke dalam kolam renang biasanya akan menjadi takut atau cemas ketika akan masuk ke dalam kolam, lebih-lebih bila pernah mengalami trauma dengan air. Untuk itu sebaiknya, mereka msuk ke dalam kolam yang dangkal terlebih dahulu. Setelah terbiasa dan keberaniannya mulai mumcul, bias mulai diajak ke kolam renang yang sedikit agak lebih dalam. Sebaiknya orang yang baru belajar masih tetap bias menginjakkan kakinya ke lantai kolam renang tanpa tenggelam.

2. Ajarkan cara membuang nafas di air.

Cara membuang nafas di air, adalah :

a. Hirup nafas dalam-dalam.

b. Kemudian masukkan kepala ke dalam air.

c. Tiupkan nafas melalui hidung ketika kepala masih dalam air.

d. Setelah itu naikkan kepala ke atas sambil membuka mulut untuk mengambil nafas.

e. Lakukan langkah di atas berulang-ulang sampai terbiasa dan tidak takut memasukkan kepala ke dalam air.

3. Melompat dari pinggir kolam ke dalam kolam renang

Melompat dari pinggir kolam renang dimaksudkan untuk mengurangi rasa takut dengan air. Dan bias lebih enjoy dan menikmati bermain-main dengan air.

4. Belajar mengapungkan badan di atas permukaan air.

Bila sudah tidak takut dengan air (berani memasukkan kepala ke dalam air cukup lama) maka selanjutnya adalah mengapungkan badan di atas permukaan air. Dengan posisi, wajah dan pandangan mata menghadap ke lantai kolam renang sambil menahan nafas (dilakukan dengan santai). 
5. Belajar meluncur di permukaan air.

Setelah bisa mengapungkan badan di atas permukaan air, tahap selanjutnya adalah meluncur. Meluncur dilakukan dengan cara pada posisi tubuh mengapung di atas permukaan air, kemudian gerakkan kaki naik turun seperti orang yang sedang berjalan (tapi antara paha dan kaki tetap lurus. Dengkul tidak boleh ditekuk).

Untuk belajar mengapung ini, awalnya bisa dibantu oleh teman untuk memegangi tangannya, ketika mengapungkan badan dengan santa di atas permukaan air dan sewaktu akan berdiri kembali. Untuk belajar mengapung dan menluncur ini, yang paling utama adalah menghilangkan rasa takut terhadap air. Kemudian praktekkan langkah-langkah di atas. Lakukan dengan santai saja, pasti berhasil.

\subsection{Peraturan Renang}

Dalam sebuah perlombaan renang, terdapat aturan-aturan yang wajib ditaati para perenang dan jika dilanggar, perenang yang bersangkutan akan mendapatkan sanksi. Peraturan renang yang berlaku saat ini adalah sebagai berikut.

- Saat perlombaan akan dimulai, wasit start meniup peluit panjang sebagai aba-aba bagi para perenang untuk naik ke balok start (untuk gaya dada, bebas, dan kupu-kupu) atau bersiap di dalam air dengan badan menghadap dinding kolam (untuk gaya punggung).

- $\quad$ Perenang harus berada dalam posisi start setelah wasit start memberikan aba-aba "siap". Startdianggap tidak sah jika ada peserta yang melompat lebih dahulu sebelum ada aba-aba.

- Posisi start untuk nomor renang yang dimulai dari atas balok start adalah badan membungkuk kea rah air dengan lutut sedikit ditekuk. Untuk gaya 
punggung, perenang memegang pegangan besi pada balok start dan kaki bertumpu pada dinding kolam dengan lutut ditekuk di antara dua lengan.

- Perenang boleh mulai melompat ketika pistol start sudah ditembakkan.

- $\quad$ Perenang harus tetap berada pada lintasannya masing-masing sesuai hasil undian atau keputusan panitia lomba.

- $\quad$ Perenang tidak boleh mengganggu peserta lain dengan cara memotong lintasan atau cara lain yang menyebabkan pelanggaran.

- Jika pelanggaran mengancam kesempatan seorang peserta untuk menang, ketua pertandingan berkuasa untuk mengizinkan peserta tersebut mengikuti lomba kembali pada babak berikutnya.

- Untuk semua nomor pertandingan, perenang harus menyentuh ujung kolam saat berbalik. Pembalikan harus dilakukan dari dinding dan perenang tidak boleh mengambil langkah dari dasar kolam.

- Berdiri di dasar kolam ketika perlombaan berlangsung tidak akan menyebabkan peserta mengalami diskualifikasi, kecuali jika berjalan.

- $\quad$ Peserta yang berenang sendiri saja harus menyelesaikan seluruh jarak renangnya lebih dahulu sebelum dinyatakan menang.

- Untuk lomba renang estafet, urutan gayanya adalah gaya punggung, gaya dada, gaya kupu-kupu, lalu gaya bebas.

- Pada lomba renang estafet, sebuah regu dapat didiskualifikasi jika ada perenang yang kakinya terlepas dari tempat start sebelum peserta terdahulu menyentung dinding kolam, kecuali jika perenang yang melakukan kesalahan tersebut kembali ke tempat start dan cukup pada dinding. 
- Setiap peserta lomba renang harus menyelesaikan perlombaan di lintasan yang sama dengan ketika saat

\subsection{Sarana dan Prasarana}

Kegiatan renang, baik saat baru berlatih, sebagai rekreasi, maupun ketika mengikuti lomba, membutuhkan beberapa peralatan sebagai berikut.

\section{Pakaian Renang}

Pakaian renang wajib digunakan baik oleh para pemula ketika berlatih renang maupun para atlet ketika berlomba.

\section{Pelampung}

Pelampung ada yang berbentuk papan, ada juga yang bentuknya seperti ban. Fungsi papan pelampung adalah untuk berlatih meluncur di atas air, sedangkan pelampung berbentuk ban berguna untuk berlatih mengambang.

\section{Kacamata Renang}

Kacamata renang berfungsi untuk melindungi mata Anda agar tidak terkena air ketika berenang.

\section{Sementara itu, untuk perlombaan berenang, sarana dan prasarana yang} disiapkan harus memenuhi ketentuan internasional sebagai berikut.

\section{Kolam Renang}

Kolam renang untuk perlombaan harus memiliki panjang 50 meter untuk lintasan panjang dan 25 meter untuk lintasan pendek. Adapun kedalaman kolam renang adalah 1,35 meter, mulai 1 meter pertama sampai minimal 0,6 meter dari dinding kolam yang dilengkapi balok start. 


\section{Lintasan}

Setiap lintasan kolam renang memiliki lebar minimal 2,5 meter dengan jarak tepi sekitar 0,2 meter di luar lintasan pertama dan terakhir. Lintasan dibatasi oleh tali yang panjangnya sama dengan panjang lintasan dan terbuat dari pelampung berukuran kecil yang diikat pada seutas tali.

Pelampung pada tali lintasan dapat berputar jika terkena gelombang dan memiliki warna berbeda sesuai nomor lintasan. Pelampung berwarna hijau digunakan untuk lintasan nomor 1 dan 8 , biru untuk lintasan nomor 2,3, 6, dan 7, sedangkan warna kuning dipakai untuk lintasan 4 dan 5.

\section{Pecatat Waktu}

Pada perlombaan renang berskala internasional, digunakan papan sentuh untuk mencatat waktu secara otomatis yang diletakkan di kedua sisi kolam renang. Perenang harus menyentuh papan yang memiliki ketebalan $1 \mathrm{~cm}$ tersebut ketika berbalik dan saat mencapai finish.

\section{Balok Start}

Balok start adalah tempat perenang bersiap memulai pertandingan dengan ukuran $0,5 \times 0,5$ meter dengan tinggi antara 0,5 hingga 0,75 meter dari permukaan air.

Bagian atas balok dilapisi bahan anti-licin untuk mencegah perenang terpeleset dan memiliki kemiringan tidak lebih dari 10 derajat.

Balok ini dilengkapi pengeras suara untuk membunyikan tembakan pistol sebagai tanda pertandingan dimulai. Selain itu, balok start juga memiliki sensor waktu untuk mencatat waktu ketika perenang mulai meloncat dari balok. 


\subsection{Manfaat Renang}

Aktivitas renang dapat dilakukan sebagai kegiatan rekreasi, hobi, atau olahraga. Jika dilakukan secara rutin, berenang akan memberikan banyak manfaat untuk tubuh, baik secara fisik maupun psikis. Berikut ini adalah beberapa manfaat yang dapat diperoleh dengan berenang.

\section{Menghilangkan Stres}

Selain meningkatkan energi tubuh, berenang membuat tubuh dan pikiran menjadi rileks. Tak heran jika banyak orang yang merasa lebih santai dan terbebas dari rasa stres dengan berenang.

\section{Meningkatkan Stamina Tubuh}

Berenang secara rutin akan membuat stamina tubuh meningkat dan daya tahan jantung pun menjadi lebih baik. Selain itu, orang yang rajin berenang lebih mudah sembuh saat mengalami cedera otot. Jika Anda merasa sering mudah lelah, cobalah berenang untuk membantu memperbaiki stamina tubuh.

\section{Meringankan Sakit dan Nyeri}

Aktivitas berenang membuat tidak membuat jaringan ikat dalam tubuh menjadi tegang sehingga olahraga ini sangat baik dilakukan oleh orang yang memiliki keterbatasan fisik. Berenang juga berguna untuk meringankan sakit dan nyeri pada penderita sakit punggung kronis, artritis, dan osteoporosis.

\section{Baik untuk Ibu Hamil}

Renang adalah salah satu jenis olahraga yang boleh dilakukan, bahkan disarankan untuk ibu hamil, selama kehamilannya sehat dan normal. Berenang membuat otot perut dan otot bahu ibu hamil menjadi kuat serta meredakan nyeri sendi. 
Selain bagi ibu, berenang juga baik untuk kesehatan janin. Hasil penelitian yang dilakukan oleh Melpomene Institute of Minneapolis juga membuktikan bahwa wanita hamil yang rutin berenang memiliki risiko keguguran yang lebih rendah.

\section{Baik untuk Penderita Kanker Payudara}

Menurut para ahli medis, berenang sangat bermanfaat untuk menguatkan kembali otot-otot yang melemah pada penderita kanker payudara yang telah menjalani operasi. Namun, sebelum memutuskan rutin berenang, pasien kanker payudara harus berkonsultasi lebih dahulu dengan dokter.

\section{Mencegah Obesitas}

Jika Anda adalah penderita obesitas dan ingin menurunkan berat badan, cobalah untuk berenang secara rutin. Gerakan renang membuat hampir seluruh bagian tubuh bekerja sehingga jumlah kalori yang dibakar sangat besar. Berenang selama 1 jam dapat membakar 800-900 kalori.

\section{Sarana Bermain dan Rekreasi}

Hampir semua anak dan balita sangat menyukai permainan air. Karena itu, kolam renang dapat menjadi sarana bermain, rekreasi, dan belajar anak. Selain menyehatkan, berenang bisa merangsang gerakan motorik anak, otot anak akan berkembang, tubuhnya lentur, dan pertumbuhan badan meningkat.

\section{Menghilangkan Rasa Takut terhadap Air}

Berenang bisa menjadi terapi bagi Anda yang memiliki rasa takut (fobia) terhadap air. Untuk menghindari rasa takut pada air, ada baiknya jika orang tua membiasakan anaknya bermain air dan berenang sejak bayi. 


\section{Menumbuhkan Sikap Positif}

Berenang sangat baik untuk menumbuhkan sikap-sikap positif dalam diri seseorang. Orang yang rutin berenang pada umumnya memiliki keberanian, rasa percaya diri, dan kemandirian yang tinggi.

\section{Meningkatkan Kemampuan Sosial}

Berenang bersama teman sekolah atau rekan kerja dapat menumbuhkan rasa kebersamaan, juga meningkatkan kemampuan beradaptasi dan bersosialisasi dengan orang lain. 


\section{BAB III}

\section{PENUTUPAN}

\subsection{Kesimpulan}

Renang merupajan cabang dari salah satu olah raga air yang telah di perlombakan sejak tahun 1800 setelah dibangunnya kolam-kolam renang. Adapun bukti tertua mengenai berenang adalah lukisan-lukisan tentang perenang dari Zaman Batu telah ditemukan di "gua perenang" yang berdekatan dengan Wadi Sora di Gilf Kebir, Mesir barat daya. Catatan tertua mengenai berenang berasal dari 2000 SM. Berenang mempunyai beberapa macam gaya diantaranya yaitu gaya bebas, gaya punggung, gaya dada dan gaya kupu-kupu.

Gaya berenang tersebut mempunyai cirri khas tersendiri dan teknik yang berbeda-beda untuk dapat mencapai kecepatan dalam berenang yang maksimal. Berenang dapat membugarkan tubuh dan untuk yang professional dapat mencetak prestasi dari tingkat nasional maupun internasional.

Namun sebaiknya dalam memulai dan sesudah nya agar tubuh tidak terjangkit efek buruk dari berenang seperti kejang-kejang. Adapun manfaat berenang itu sendiri adalah meningkatkan kualitas jantung dan peredaran darah, meningkatkan kapasitas vital paru - paru dan mempengaruhi otot mejadi berisi. 


\section{Daftar Pustaka}

1. https://www.romadecade.org/sejarah-renang/

2. https://salamadian.com/pengertian-renang

3. https://id.wikipedia.org/wiki/Renang_(olahraga)

4. https://annisawally0208.blogspot.com/2018/10/contoh-makalah-tentang-renang.html 5.https://docs.google.com/document/u/0/d/1uEsFPI1raUci2Sw_XGNn4-11wn3x8dqMI H2wjLX6MTA/mobilebasic 